\title{
GENE-DELETION AND CARRIER DETECTIONS, AND PRENATAL DIAGNOSIS OF DUCHENNE MUSCULAR DYSTROPHY BY ANALYSIS OF THE DYSTROPHIN GENE AMPLIFIED BY POLYMERASE CHAIN REACTION
}

\author{
Satoshi Fujishita, ${ }^{1,2, *}$ Noritoshi Shibuya, ${ }^{1}$ Norio Nilkawa, ${ }^{3}$ \\ and Shigenobu NAGATAKI ${ }^{2}$ \\ ${ }^{1}$ Department of Neurology, Kawatana National Hospital, \\ Kawatana, Nagasaki 859-36, Japan \\ ${ }^{2}$ First Department of Internal Medicine, and \\ "Department of Human Genetics, Nagasaki University School of Medicine, \\ Sakamoto-machi 12-4, Nagasaki 852, Japan
}

\begin{abstract}
Summary Polymerase chain reaction (PCR)-based diagnosis was carried out in 62 patients (57 probands) with Duchenne or Becker muscular dystrophy (DMD or BMD) and 226 members in 57 families. The PCR studies were also performed for carrier detection in 57 mothers and 58 sisters, and prenatal diagnosis of 4 fetuses at risk of DMD. The PCR with 7 sets of primers, which amplify 7 different exon-sequences of the dystrophin gene, detected gene deletion of at least one exon in $49 \%$ of the probands. The PCR with the other 4 primer sets, which amplify 3 intragenic loci, and subsequent endonuclease digestion detected in $84 \%$ of the mothers a heterozygous pattern in at least one such locus/segment. Using the same primer sets, carrier detection was successful in 5 sisters of familial DMD cases, while recombination between the ERT87 and the $3^{\prime}$ end intragenic loci was observed in $11 \%$ of family members studied. Prenatal diagnosis was made in all the 4 fetuses; two males were affected, one male fetus non-affected, and the remaining one female fetus a carrier. Thus, the PCR study and the primers used in the present study are useful and convincing for rapid diagnosis of DMD and/or BMD.
\end{abstract}

Key Words Duchenne muscular dystrophy, polymerase chain reaction, gene deletion, carrier detection, prenatal diagnosis

\section{INTRODUCTION}

Duchenne muscular dystrophy (DMD) is an X-linked recessive disorder caused Received September 30, 1991; revised version received November 24, 1991, Accepted December 12,1991 .

* To whom correspondence should be addressed. 
by a mutation in the dystrophin gene localized at Xp21 (Kunkel et al., 1986; Koenig et al., 1987, 1989; Blonden et al., 1991). Molecular analysis with the dystrophin cDNA and flanking or intragenic polymorphic DNA markers (Davies et al., for Human Gene Mapping 10.5, 1990) has made DNA-based diagnosis possible (Blonden et al., 1991). However, traditional Southern blot analysis requires the use of isotopic DNA probes and several restriction enzymes, and spends several days to detect a gene deletion or mutation-linked restriction fragment length polymorphisms (RFLPs). By the use of recently developed in vitro DNA amplification method with the polymerase chain reaction (PCR) (Saiki et al., 1987), the deletion of the dystrophin gene can be detected easily, leading to a rapid diagnosis (Chamberlain et al., 1988; Roberts et al., 1989; Beggs et al., 1990a, 1990b).

This paper deals with the PCR-based diagnosis of gene deletion, carrier detection and prenatal diagnosis in a number of Japanese DMD/BMD families.

\section{MATERIALS AND METHODS}

Genomic DNA was extracted with the salt-precipitation technique from peripheral blood leukocytes of $62 \mathrm{DMD} / \mathrm{BMD}$ patients including 57 probands from 57 families, all their mothers and 58 sisters of the probands, and from chorionic villi of 4 ( 3 male and one female) fetuses at risk of DMD, biopsied at the 10th gestational week. In all the patients, the diagnosis of $\mathrm{DMD} / \mathrm{BMD}$ was made by clinical examinations, family history, serum creatine kinase values and/or muscle biopsy findings. In 41 of the 57 families, the proband was an isolated case, while in 16 families there were two or more affected male individuals (familial cases).

Eleven sets of synthesized oligonucleotide primers were prepared according to the sequences of the dystrophin CDNA or to the intragenic sequences using an automated DNA synthesizer (Applied Biosystems) (Roberts et al., 1989; Beggs et al., 1990a; Prior et al., 1990a) (Table 1). Seven of the 11 primer sets which were used for deletion analysis covered the following 7 exons: exons 4, 8, 19, 45, 47, 51, and 52. The other 4 primer sets involved 4 intragenic sequences, ERT87-8 and ERT87-15 (Roberts et al., 1989), and the $3^{\prime}$ end sequence (base pairs 11,727-11,758) (Beggs et al., 1990a) of the dystrophin gene. These 4 primer sets were used especially for detection of intragenic polymorphic fragments. The primer DNA was purified by repeated co-evaporation with double-distilled water.

PCR was carried out for 30 cycles with a modification of the method by Chamberlain et al. (1988) in $50 \mu \mathrm{l}$ reaction mixture consisting of $200 \mathrm{nM}$ each of dNTP, $250 \mathrm{~mm}$ each of the primers, $10 \mathrm{mM}$ Tris- $\mathrm{HCl}$ (pH 8.0), $1.5 \mathrm{mM} \mathrm{MgCl}_{2}, 50$ $\mathrm{mM} \mathrm{KCl}, 2.5 \mathrm{U}$ Taq DNA polymerase, and $50 \mathrm{ng}$ of genomic DNA as a template. Primer annealing was conducted at $92^{\circ} \mathrm{C}$ for $90 \mathrm{sec}$, extension at $62^{\circ} \mathrm{C}$ for $90 \mathrm{sec}$, denaturation at $72^{\circ} \mathrm{C}$ for $90 \mathrm{sec}$, and the final extension for $10 \mathrm{~min}$, using an automated temperature controller (Program Temp Control System, Astec Co., Tokyo). Ten $\mu \mathrm{g}$ of the PCR product was digested with one of the following three restriction 
Table 1. Primers used in the present PCR study.

\begin{tabular}{|c|c|c|}
\hline Primer set & $\begin{array}{l}\text { Intragenic } \\
\text { locus }\end{array}$ & Sequence $\left(5^{\prime}-3^{\prime}\right)$ \\
\hline $\begin{array}{l}\text { pERT87-8TaqIL } \\
\text { pERT87-8TaqIR }\end{array}$ & ERT87-8 & $\begin{array}{l}\text { GTCAGTTGGTCAGTAAAAGCC } \\
\text { CCAATTAAAACCACAGCAG }\end{array}$ \\
\hline $\begin{array}{l}\text { pERT87-15BamHIL } \\
\text { pERT87-15BamHIR }\end{array}$ & ERT87-15 & $\begin{array}{l}\text { TCCAGTAACGGAAAGTGC } \\
\text { ATAATTCTGAATAGTCACAAAAAG }\end{array}$ \\
\hline $\begin{array}{l}\text { pERT37-15XmnIL } \\
\text { pERT87-15XmnIR }\end{array}$ & ERT87-15 & $\begin{array}{l}\text { GACTGGAGCAAGGGTCGCC } \\
\text { ACAATTTCCCTTTCATTCCAG }\end{array}$ \\
\hline $\begin{array}{l}3^{\prime} \text { CA-F } \\
3^{\prime} \text { CA-R }\end{array}$ & $3^{\prime}$ end & $\begin{array}{l}\text { GAAAGATTGTAAACTAAAGTGTGC } \\
\text { GGATGCAAAACAATGCGCTGCCTC }\end{array}$ \\
\hline $\begin{array}{l}4 \mathrm{~F} \\
4 \mathrm{R}\end{array}$ & exon 4 & $\begin{array}{l}\text { TTGTCGGTCTCCTGCTGGTCAGTG } \\
\text { CAAAGCCCTCACTCAAACATGAAGC }\end{array}$ \\
\hline $\begin{array}{l}8 \mathrm{~F} \\
8 \mathrm{R}\end{array}$ & exon 8 & $\begin{array}{l}\text { GTCCTTTACACACTTTACCTGTTGAG } \\
\text { GGCCTCATTCTCATGTTCTAATTAG }\end{array}$ \\
\hline $\begin{array}{l}19 \mathrm{~F} \\
19 \mathrm{R}\end{array}$ & exon 19 & $\begin{array}{l}\text { TTCTACCACATCCCATTTTCTTCCA } \\
\text { GATGGCAAAAGTGTTGAGAAAAAGTC }\end{array}$ \\
\hline $\begin{array}{l}45 \mathrm{~F} \\
45 \mathrm{R}\end{array}$ & exon 45 & $\begin{array}{l}\text { AAACATGGAACATCCTTGTGGGGAC } \\
\text { CATTCCTATTAGATCTGTCGCCCTAC }\end{array}$ \\
\hline $\begin{array}{l}47 \mathrm{~F} \\
47 \mathrm{R}\end{array}$ & exon 47 & $\begin{array}{l}\text { CGTTGTTGCATTTGTCTGTTTCAGTTAC } \\
\text { GTCTAACCTTTATCCACTGGAGATTTG }\end{array}$ \\
\hline $\begin{array}{l}51 \mathrm{~F} \\
51 \mathrm{R}\end{array}$ & exon 51 & $\begin{array}{l}\text { GAAATTGGCTCTTTAGCTTGTGTTTC } \\
\text { GGAGAGTAAAGTGATTGGTGGAAAATC }\end{array}$ \\
\hline $\begin{array}{l}52 \mathrm{~F} \\
52 \mathrm{R}\end{array}$ & exon 52 & $\begin{array}{l}\text { AATGCAGGATTTGGAACAGAGGCGTCC } \\
\text { TTCGATCCGTAATGATTGTTCTAGCCTC }\end{array}$ \\
\hline
\end{tabular}

enzymes, TaqI, XmnI and BamHI for over one hour according to the manufacturers' recommendation. The digests were electrophoresed on $8-16 \%$ polyacrylamide or $2 \%$ agarose gel, and visualized by ethidium bromide staining. In parallel to the PCR study, conventional Southern blot analysis was done using the dystrophin cDNA probes to detect gene deletions.

\section{RESULTS}

\section{Deletion analyses}

Using the 7 exon-amplifiable primer sets, deletion of at least one exon was detected in $26(49 \%)$ of 53 probands studied. Southern blot analyses with the cDNA probes corresponding to the sequences amplified with the primers showed a deletion in 28 probands of the same series. Thus, 2 deletions were not detected by the PCR analysis, one deletion involved exon 18 and the other was within exon 17 , for which we did not use any primer-sets. The distribution of deletion sites detected in the present study was similar to that detected with the previous cDNA 
Southern blot analysis among Japanese DMD patients (Sugino et al., 1989) and that among Caucasian patients (den Dumnen et al., 1989).

\section{Polymorphism analyses}

The size of polymorphic DNA fragments (the PCR products) detected with each of the 4 primer sets and their allele frequencies among female members of the 57 DMD families are shown in Table 2. Three of the polymorphisms were RFLPs, and the other that was detected with the $3^{\prime} \mathrm{CA}$ primer set is most likely a deletion polymorphism. Forty-eight $(84 \%)$ of the 57 mothers showed heterozygous patterns for at least one of the intragenic loci examined. Of the 13 sisters of the 16 familial cases, 5 had a haplotype identical to that in their respective proband, indicating that these sisters are carriers. On the other hand, a different haplotype from that of the proband was observed in 17 sisters, regardless of familial or sporadic cases (Table 3). Thus, carrier or non-carrier detection was successful in 22 sisters from 57 families. In 4 of 36 family members, whose genotypes could

Table 2. Size of polymorphic DNA fragment and allele frequency detected by the present PCR method.

\begin{tabular}{lccccc} 
Primer set & Enzyme & \multicolumn{2}{c}{ Allele } & No. of \\
& & Size $(\mathrm{bp})$ & Frequency & PIC a & $\begin{array}{c}\text { Nomosomes } \\
\text { chrom }\end{array}$ \\
pERT87TaqIL & Taql & 145 & 0.69 & 0.36 & 108 \\
pERT87TaqIR & & $74+71$ & 0.31 & & \\
pERT87-15BamHIL & Bam HI & 216 & 0.28 & 0.32 & 50 \\
pERT87-15BamHIR & & $166+50$ & 0.72 & & \\
pERT87-15XmnIL & XmnI & 730 & 0.53 & 0.43 & 102 \\
pERT87-15XmnIR & & $520+210$ & 0.47 & & \\
3' CA-F & & 137 & 0.19 & 0.37 & 102 \\
3' CA-R & - & 133 & 0.81 & &
\end{tabular}

a PIC, polymorphism information content.

Table 3. Number of sisters with haplotypes detected by the present PCR study.

\begin{tabular}{lcc} 
& \multicolumn{2}{c}{ DMD } \\
\hline Haplotype in sister & Familial & Sporadic \\
\hline Identical to proband's & 5 & 20 \\
Different from proband's & 5 & 12 \\
(recombination) & $(1)$ & $(3)$ \\
Not determined & 3 & 13 \\
\hline Total number of sisters & 13 & 45 \\
Number of families & 13 & 39 \\
\hline
\end{tabular}

Jpn. J. Human Genet. 


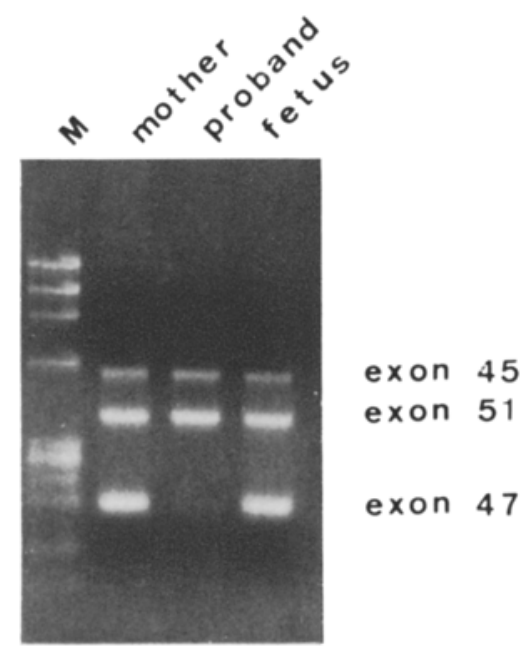

Fig. 1. PCR DNA-amplification for prenatal diagnosis of a DMD family. Note that the fragment corresponding to the exon 47 is missing in the proband, while that is present in the fetus. $M$, size marker DNA.

be traced, recombinations had occurred between the ERT87 locus and the $3^{\prime}$ end portion of the gene.

\section{Prenatal diagnosis}

Prenatal diagnosis was successful in all of the 4 fetuses examined. Two male fetuses were affected because of having a haplotype identical to that in their respective probands in whom any deletion was not detected. One male fetus was nonaffected because of both having the segment in which the proband showed deletion (Fig. 1) and having a haplotype different from that in the proband. The remaining one female fetus was diagnosed as a carrier from her haplotypes.

\section{DISCUSSION}

Since $50-65 \%$ of gene deletions in DMD/BMD patients were observed in certain hot-spots within the gene, we first selected 7 exon-amplifiable primer sets. The deletion was found in $49 \%$ of the patients studied. Beggs et al. (1990a) and Chamberlain et al. (1988) reported that over $98 \%$ of cDNA-detectable deletions were detected by the PCR analysis using the primers covering 18 exons of the dystrophin gene. Although we employed only 7 primer sets, a similar detection rate was obtained in the present FCR study: $26(92 \%)$ of 28 deletions observed with Southern analyses were detected by PCR. Even if comparing with the result of our previous whole-cDNA study (Sugino et al., 1989), these PCR-detected deletions would cover $93 \%$ of those observed in the cDNA study. Thus, the deletions in 
our present series of DMD patients may have occurred in such hot-spots.

Using the 4 primer sets that detect polymorphisms in the dystrophin gene, $84 \%$ of mothers of the patients were shown to be heterozygous for at least one of the three intragenic loci. The allele frequencies detected with three combinations of primer-set/enzyme (pERT87-8TaqI/TaqI, pERT87-15BamHI/BamHI, and pERT$87-15 \mathrm{Xmnl} / \mathrm{XmnI}$ ) were well comparable to those obtained from the previous study with the cDNA-probes in Japanese females (Sugino et al., 1989), but different in several loci from those in the Caucasian (Davies et al., for Human Gene Mapping $10.5,1990$ ). Therefore, these 4 primers are useful for carrier detection in the Japanese. Recombinations between the ERT87-8 locus and the 3 ' end portion of the gene occurred in 4 of 36 members examined in our study, a recombination fraction being $11 \%$. Abbs et al. (1990) reported a fraction of $9.2 \%$ between the two intragenic loci, being comparable to that in our study. This often makes it difficult to detect carriers accurately. Thus, more studies are needed to find novel RFLPS in more intragenic loci. Another problem for carrier detection includes the presence of germinal mosaicism (Bakker et al., 1987). In this case, PCR analysis dose not in general contribute to find such a condition, and therefore, gene dose analysis with Southern hybridization is still important.

Prenatal diagnosis was successful in all four our fetuses examined. Fortunately, none of them showed any deletions. There is a problem that when a fetus at risk of DMD is expected to have no deletion, polymorphic analysis shows a recombination in 5 to $10 \%$. Since PCR analysis has a pitfall showing a maternal DNA contamination as a potential artifact. In this case, deletion in a fetus would be overlooked, as far as only the conventional PCR method is used as a diagnostic aid. Recently, a quantitative PCR analysis method has been developed (Prior et al., 1990b). However, this technique has remained to be elucidated whether it is truly efficient for carrier detection or detection of duplication of the dystrophin gene.

Acknowledgments We express our gratitude to Dr. Y. Jinno and Dr. T. Matsumoto, Nagasaki University School of Medicine, and to Mr. N. Harada, Kyushu Medical Science, Nagasaki Laboratory, for their technical advice.

This work is supported by a grant for Genetic Analysis of Duchenne Muscular Dystrophy from the Ministry of Health and Welfare of Japan.

\section{REFERENCES}

Abbs, S., Roberts, R.G., Mathew, G.G., Bentley, D.R. and Bobrow, M. 1990. Accurate assessment of intragenic recombination frequency within the Duchenne muscular dystrophy gene. Genomics 7: 602-606.

Bakker, E., van Broeckhoven, C., Bonten, E.J., van de Vooren, M.J., Veenema, H., van Hul, W., van Omen, G.J.B., Vandenberghe, A. and Pearson, P.L. 1987. Germline mosaicism and Duchenne muscular dystrophy mutations. Nature 329: 554-556.

Beggs, A.H., Koenig, M., Boyce, F.M. and Kunkel, L.M. 1990a. Detection of $98 \%$ of DMD/ BMD gene deletions by polymerase chain reaction. Hum Genet. 86: 45-49. 
Beggs, A.H. and Kunkel, L.M. 1990b. A polymorphic CACA repeat in the 3 untranslated region of dystrophin. Nucleic Acids Res. 18: 1931.

Blonden, L.A.J., Grootsscholten, P.M., den Dunnen, J.T., Bakker, E., Abts, S., Bobrow, M., Boehm, C., van Broeckhoven, C., Baumbach, L., Chamberiain, J., Caskey, C.T., Denton, M., Felicetti, L., Galluzi, G., Fischbeck, K.H., Francke, U., Darras, B., Gilgenkrantz, H., Kaplan, J.-C., Herrmann, F.H., Junien, C., Boileau, C., Liechti-Gallati, S., Lindorf, M., Matsumoto, T., Niikawa, N., Muller, C.R., Poncin, J., Malcolm, S., Robertson, E., Romeo, G., Cocone, A.E., Scheffer, H., Schroder, E., Schwartz, M., Verellen, C., Walker, A., Worton, R., Gillard, E. and van Ommen, G.J.B. 1991. 242 breakpoints in the 200-kb deletion-prone P20 region of the DMD gene are widely spread. Genomics 10: 631-639.

Chamberlain, J.S., Gibbs, R.A., Ranier, J.E., Nguen, P.N. and Caskey, C.T. 1988. Deletion screening of the Duchenne muscular dystrophy locus via multiplex DNA amplification. Nacleic Acids Res. 16: 11141-11156.

Davies, K.E., Mandel, J.L., Monaco, A.P., Nussbaum, R.L. and Willard, H.F. 1990. Report of the committee on the genetic constitution of the X chromosome (for Human Gene Mapping 10.5). Cytogenet. Cell Genet. 55: 254-313.

den Dunnen, J.T., Grootscholten, P.M., Bakker, E., Blonden, L.A.I., Ginjaar, H.B., Wapenaar, M.C., van Paassen, H.M.B., van Broeckhoven, C., Pearson, P.L. and van Ommen, G.J.B. 1989. Topography of the Duchenne muscular dystrophy (DMD) gene: FIGE and cDNA analysis of 194 cases reveals 115 deletions and 13 duplications. Am. J. Hum. Genet. 45: 835-847.

Koenig, M., Hoffman, E.P., Bertelson, C.J., Monaco, A.P., Feener, C., Kunkel, L.M. 1987. Complete cloning of the Duchenne muscular dystrophy (DMD) cDNA and preliminary genomic organization of the DMD gene in normal and affected individuals. Cell 50: 509-517.

Koenig, M., Beggs, A.H., Moyer, M., Scherph, S., Heindrich, K., Bettecken, T., Meng, G., Muller, C.R., Lindlof, M., Kaariainen, H., de la Chapelle, A., Kiuru, A., Savontaus, M.L., Gilgenkrantz, H., Recan, D., Chelly, J., Kaplan, J.C., Covone, A.E., Archidiacono, N., Romeo, G., Liechti Gallati, S., Schneider, V., Braga, S., Moser, H., Darras, B.T., Murphy, P., Francke, U., Chen, J.D., Morgan, G., Denton, M., Greenberg, C.R., Wrogemann, K., Blonden, L.A.J., van Paassen, H.M.B., van Ommen, G.J.B. and Kunkel, L.M. 1989. The molecular basis for Duchenne versus Becker muscular dystrophy: Correlation of severity with type of deletion. Am. J. Hum. Genet. 45: 498-506.

Kunkel, L.M., Hejtmancik, J.F., Caskey, C.T., Speer, A., Monaco, A.P., Middlesworth, W., Colletti, C.A., Bertelson, C., Muller, U., Bresnan, M., Shapiro, F., Tantravahi, U., Speer, J., Latt, S.A., Bartlett, R., Pericak-Vance, M.A., Roses, A.D., Thompson, M.W., Ray, P.N., Worton, R.G., Fishbeck, K.H., Gallano, P., Coulon, M., Duros, C., Boue, J., Junien, C., Chelly, J., Hanmard, G., Jeanpierre, M., Lambert, M., Kaplan, J.C., Emery, A., Dorkins, H., McGlade, S., Davis, K.E., Boehm, C., Arveiler, B., Lemaire, C., Morgan, G.J., Denton, M.J., Amos, J., Bobrow, M., Benham, F., Boswinkel, E., Cole, C., Dubowitz, V., Hart, K., Hodgson, S., Johnson, L., Walker, A., Fergusson-Smith, M.A., Lindlof, M., Kaariainen, H., de la Chapelle, A., Ianasescu, V., Searby, C., Ionasescu, R., Bakker, E., van Ommen, G.J.B., Pearson, P.L., Greenberg, C.R., Hamerton, J.L., Wrongemann, K., Doherty, R.A., Polakowska, R., Hyser, C., Quirk, S., Thomas, N., Harper, J.F., Darras, B.T. and Francke, U. 1986. Analysis of deletions in the DNA from patients with Becker and Duchenne muscular dystrophy. Nature 322: 73-77.

Prior, T.W., Highsmith, W.E., Jr., Friedman, K.J., Perry, T.R., Scheuerbrandt, G. and Silverman, L.M. 1990a. A model for molecular screening of newborns: Simultaneous detection of Duchenne/Becker muscular dystrophies and cystic fibrosis. Clin. Chem. 36: 1756-1759.

Prior, T.W., Papp, A.C., Snyder, P.J., Highsmith, W.E., Jr., Friedman, K.J., Perry, T.R., Silverman, L.M. and Mendell, J.R. 1990b. Determination of carrier status in Duchenne and Becker muscular dystrophies by quantitative polymerase chain reaction and allele-specific oligonucleotides. Clin. Chem. 36: 2113-2117. 
Roberts, R.G., Cole, C.G., Hart, K.A., Bobrow, M. and Bently, D.R. 1989. Rapid carrier and prenatal diagnosis of Duchenne and Becker muscular dystrophy. Nucleic Acids Res. 17: 811.

Saiki, R.K., Gelfand, D.H., Stoffel, S., Scharf, S.J., Higuchi, R., Horn, G.T., Mullis, K.B. and Erlich, H.A. 1987. Primer-directed enzymatic amplification of DNA with a thermostable DNA polymerase. Science 239 : 487-491.

Sugino, S., Fujishita, S., Kamimura, N., Matsumoto, T., Wapenaar, M.C., Deng, H.X., Shibuya, N., Miike, T, and Niikawa, N. 1989. Molecular-genetic study of Duchenne and Becker muscular dystrophies: Deletion analyses of 45 Japanese patients and segregation analyses in their families with RFLPs based on the data from normal Japanese females. Am. J. Med. Genet. 34: $555 \cdots 561$. 